удК 342.9

DOI https://doi.org/10.32837/pyuv.v0i1(30).534

\author{
Б. В. Чернявська \\ orcid.org/0000-0001-8263-7483 \\ аспірантка кафедри адміністративного права \\ юридичного факультету \\ Київського національного університету імені Тараса Шевченка, \\ юрист Наукового иентру німеиького права
}

\title{
РОЛЬ ІНСТИТУТІВ ГРОМАДЯНСЬКОГО СУСПІЛЬСТВА В ДІЯЛЬНОСТІ ПУБЛІЧНОЇ АДМІНІСТРАЦІЇ: УКРАЇНСЬКИЙ ТА МІЖНАРОДНИЙ АСПЕКТ
}

Вступ. Інститут громадянського суспільства (далі - IГC) - категорія надзвичайно широка та варіативна. Над дослідженням їі проблематики працюють учені - представники різних наук: юриспруденції, філософії, політології, державного управління, соціології та інших. Проводячи теоретичне дослідження наукової літератури, ми проаналізували велику кількість визначень ІГС, дослідження їх впливу на формування правової держави, становлення демократії і верховенства права. Водночас ми виявили недостатньо розкритим питання ролі ІГС в діяльності публічної адміністрації. Варто зазначити, що держава не може імперативно декларувати обов'язок ІГС взаємодіяти із суб'єктами публічного адміністрування (далі - СПА), а лише визначати порядок їх створення, певні рамки діяльності, механізм взаємодії з іншими суб'єктами. Отже, становлення правової держави починається саме з ініціативи до взаємодії від ІГС та за сприяння держави.

Разом із тим однією з основних проблем сучасної демократії є те, що громадяни в більшості своій відчужені від політичних процесів. Безперечно, громадянське суспільство є важливою частиною демократичного процесу, адже в такий альтернативний спосіб громадяни можуть поряд із політичними партіями висловлювати різні погляди i забезпечувати свої різноманітні інтереси у процесі прийняття рішень. На жаль, не всі громадяни знають про можливості брати участь у державних процесах, а деякі просто не бажають цього робити. Отже, завданням держави є також поширювати інформацію та ініціювати діалог.

Метою статті є дослідження ролі інститутів громадянського суспільства в діяльності суб'єктів публічної адміністрації через призму українського та міжнародного досвіду, аналіз основних сфер, в яких здійснюється взаємодія цих суб'єктів, виокремлення проблем, які можуть виникати щодо їх взаємодії та пошук шляхів вирішення.

Виклад основного матеріалу. Подальше дослідження не буде ефективним без належного розуміння основних категорій, що використовуються в статті, а саме "громадянське суспільство» та «інститут громадянського суспільства».
Уперше визначення громадянського суспільства було надане Георгом Ф. В. Хегелем у його «Філософії права» як діалектична сукупність відносин між сім'єю, громадянським суспільством та державою [1, с. 228]. Як влучно зазначає B.I. Московець, громадянське суспільство - це система, що має свої механізми розвитку та управління, тобто: 1) громадяни, які вступають у різні відносини, реалізовують свої потреби та забезпечують цілеспрямований розвиток суспільства без втручання державних структур; 2) громадянська ініціатива, громадянський обов'язок дають можливість для розвитку всіх структур громадянського суспільства [2, с. 39]. Ян Арт Шольте характеризує громадянське суспільство як простір, у якому люди на добровільній основі прагнуть забезпечення дотримання правил. Таким чином, громадянське суспільство пропонує реформування наявних норм на основі взаємодії з публічною адміністрацією [3, с. 6]. Аналізуючи наведені вище визначення, пропонуємо виділити такі ознаки громадянського суспільства:

- добровільність;

- організованість;

- участь громадян у задоволенні потреб суспільства;

- забезпечення державою саморегуляції його внутрішніх відносин;

- невтручання держави у його діяльність;

- взаємодія з державою;

- сприяння розвитку держави.

На основі цих ознак пропонуємо власне визначення громадянського суспільства як організованої самоврядної участі громадян у житті суспільства з метою забезпечення його потреб, взаємодії 3 державою та сприяння її розвитку.

У теорії права визначається, що інститут - це частина певної системи. Перекладаючи це поняття на категорію громадянського суспільства, яка є комплексним і цілісним явищем, можна дійти висновку, що інститут громадянського суспільства - це її частина. Таким чином, ознаки, які характеризують громадянське суспільство, можуть бути застосовані до ІГС.

Звернемося до нормативно-правової бази України. Переходячи до характеристики інститутів 
громадянського суспільства, варто наголосити, що їх перелік є фактично невичерпним. Так, постановою Кабінету Міністрів України «Про створення єдиної системи залучення, використання та моніторингу міжнародної технічної допомоги» № 153 від 15 лютого 2002 року [4] передбачено, що інститути громадянського суспільства - громадські об'єднання, релігійні, благодійні організації, творчі спілки, професійні спілки та їх об'єднання, організації роботодавців та їх об’єднання, недержавні засоби масової інформації, легалізовані відповідно до законодавства України. Світовий банк до переліку ІГС включає широке коло суб'єктів: спілки, неурядові організації, професійні спілки, організації корінного населення, благодійні організації, релігійні організації, професійні організації і фонди [5].

Для належного розкриття взаємодії ІГC та публічної адміністрації (далі - ПА), необхідно більш детально розкрити значення останньої. Зазвичай під цим поняттям мають на увазі здійснення державної політики значною мірою органами виконавчої влади. Однак не тільки органи виконавчої влади належать до суб'єктів останньої. Ми погоджуємося з думкою Р.С. Мельника, який визначає, що публічна адміністрація є узагальнюючим терміном, що об’єднує у собі суб'єктів, головним завданням яких є виконання Конституції та законів України. До суб'єктів публічної адміністрації необхідно віднести насамперед:

1) органи виконавчої влади;

2) органи місцевого самоврядування;

3) суб'єктів делегованих повноважень (у разі коли вони виконують функції органу виконавчої влади або органу місцевого самоврядування) [6, с. 42].

Для стимулювання відносин між ІГС та ПА у ряді країн створено певні органи з координації та площадки для діалогу. Зокрема, найчастіше такими органами є: урядові органи, такі як контактна особа по роботі з громадянським суспільством при кожному міністерстві або центральний координаційний орган як єдиний контактний представник; спільні структури, такі як багатосторонні комітети, робочі групи, експертні ради та інші консультативні органи (постійні або спеціальні); або альянси (коаліції) неурядових організацій, які об'єднують ресурси і розробляють спільні позиції [7]. Однак, на жаль, у деяких країнах, хоча номінально й існують ці органи, проте вони діють дуже аморфно, переважно безініціативно. Подібна ситуація має місце і в України, про що буде сказано далі.

Взаємовідносини між ІСГ та публічною адміністрацією повинні бути врегульовані. Таке регулювання в нашій країні здійснюється на основі КонституціїУкраїни, ЗаконівУкраїни, міжнароднихактів, підзаконних нормативно-правових актів, договорів, меморандумів, установчими документами IГС.
На Форумі Ради Свропи «За майбутнє демократії», що відбулась у Швеції в червні 2007 року, учасники закликали Конференцію МНВО Ради Європи підготувати Кодекс рекомендованої практики громадської участі, який буде охоплювати такі теми, як механізм участі неурядових організацій у процесі прийняття рішень та залучення громадянського суспільства у громадську політику. Комітет міністрів Ради Свропи визнав у Рекомендації CM / Rec (2007) 14, прийнятій у жовтні 2007 року, «найважливіший внесок неурядових організацій в розвиток і здійснення демократії і прав людини, зокрема, у сприянні просвіті суспільства, участі в суспільному житті та забезпеченні прозорості й підзвітності органів державного управління» [7].

Одним із прикладів міжнародного регулювання відносин між ІСГ та ПА є прийняті учасниками багатосторонньої зустрічі, організованої Радою Європи, «Фундаментальні принципи щодо статусу неурядових організацій в Європі» (категорія НУО за своїм змістом є тотожною ІГС - прим. авт.). Ними передбачається:

- входження компетентної і відповідальної НУО до процесу формулювання державної політики збільшує застосовність законодавства і серйозність урядового прийняття рішень. Саме тому НУО повинні заохочуватися брати участь в урядових і квазіурядових механізмах для діалогу, консультації й обміну, з метою пошуку шляхів вирішення потреб суспільства. Ця участь відмінна від ролі політичних партій і не заміняє їі (п. 74);

- урядові органи можуть працювати з НУО для досягнення цілей державної політики, але не повинні намагатися заволодіти ними чи змусити їх працювати під своїм контролем (п. 77) [8].

У багатьох європейських країнах було розроблено рамкові угоди, що дозволяють визначити заходи, роль та відповідальність, а також процедури співробітництва між громадянським суспільством та суб'єктами публічної адміністрації. Ці документи являють собою чітке підгрунтя для взаємин і тим самим сприяють постійному діалогу та взаєморозумінню між неурядовими організаціями і СПА. Це, зокрема, двосторонні угоди з парламентом або урядом, стратегічні документи на підтримку співпраці й офіційні програми співробітництва, прийняті органами державного управління [9].

Основним нормативно-правовим актом, який декларує побудову відносин між інститутами громадянського суспільства та суб'єктами публічної адміністрації в Україні, є Національна стратегія сприяння розвитку громадянського суспільства в Україні на 2016-2020 роки, затверджена Указом Президента від 26 лютого 2016 року № 68/2016 [10]. Загалом, даний акт носить у цілому описовий характер, вказуючи 
на ті сфери, в яких повинна відбуватися співпраця, та наділяючи повноваженнями Координаційну раду сприяння розвитку громадянського суспільства і Кабінет Міністрів України. Слід звернути увагу на той факт, що Координаційна рада сприяння розвитку громадянського суспільства станом на 2019-2020 роки не провела жодного засідання. Відповідно до Указу Президента Кабінет Міністрів України зобов'язаний до 10 січня кожного року дії стратегії затверджувати плани заходів з реалізації Стратегії. Однак станом на травень 2020 року такий план відсутній. Отже, в 2020 році не здійснюються заходи на виконання Указу Президента. Таким чином, фактично зупинено участь держави у сприянні громадянському суспільству.

Політичний порядок денний виробляється парламентом і урядом, але він може визначатися і ІГС, зокрема неурядовими організаціями або їх об'єднаннями, завдяки кампаніям і лобіюванню щодо окремих питань, потреб і сфер. Нові політичні ініціативи часто є результатом впливу кампаній, що проводяться ІГС. На цьому етапі ІГС мають на меті вплинути на політичних керівників заради колективних інтересів і діяти таким чином, щоб це доповнювало політичні дискусії [11]. Проте, як було зазначено вище, відсоток активних громадян залишається доволі низьким. На нашу думку, ця проблема може виникати з таких причин:

- відсутність громадянської освіти;

- необізнаність населення про можливість впливу на державні та політичні процеси;

- недовіра до влади;

- правовий нігілізм населення;

- відсутність нормативно-правового механізму регулювання відносин ІГС та СПА;

- бюрократичні перепони;

- відсутність дискусійної платформи, дієвого органу координації взаємовідносин ІГС та СПА або його пасивність;

- несприятливі умови для діяльності ІГС тощо.

Необхідно наголосити на тому, що діяльність публічної адміністрації визначається її компетенцією. Г. Атаманчук стверджує, що компетенція органу держави - це сукупність функцій і повноважень з управління певними об'єктами (процесами), відношеннями, явищами, поведінкою i діяльністю людей [12, с. 547]. Цілком слушною є думка M.М. Андріїва, який переконаний, що компетенція має офіційне визначення в нормах права [13, с. 2]. Залежно від юрисдикції компетенція органів публічної адміністрації відрізняється. На підставі аналізу нормативно-правових актів можна виділити основні сфери компетенції публічної адміністрації, властиві більшості держав: безпека, охорона здоров’я, фінанси, міжнародна діяльність, юстиція, економіка, екологія, соціальна сфера, освіта. Тож для детального розумін- ня ролі ІГС в діяльності публічної адміністрації пропонуємо розглянути приклади їх участі в кожній із вищеназваних сфер.

Безпека. Чимало міжнародних ІГС працюють у сфері безпеки, вирішення конфліктів і подолання їх наслідків. Одним із найяскравіших представників таких IГC є Міжнародний комітет Червоного Хреста - незалежна, політично нейтральна організація, гуманітарні місії якої спрямовані на захист життя й гідності жертв воєнних конфліктів та інших проявів насилля. Також МКЧХ працює у сфері розвитку міжнародного гуманітарного права та поширення його принципів [14]. Прикладом діяльності МКЧХ є направлення в зону воєнного конфлікту на Донбасі 200 тонн гуманітарної допомоги. Таким чином, ми можемо бачити, як цей ІГС допомагає Міністерству з питань тимчасово окупованих територій та внутрішньо переміщених осіб, що затверджене постановою Кабінету Міністрів України від 8 червня 2016 року № 376, в якому передбачено сприяння жителям окупованих територій, забезпечення їхніх прав і свобод, реалізація гуманітарної політики.

Охорона здоров'я. Допомога ІГС публічній адміністрації в контексті пандемії коронавірусу Covid-19 набуває надзвичайно широких масштабів. В умовах потреби ефективного і швидкого реагування IГС забезпечують лікарів і пацієнтів необхідним захистом, медикаментами, обладнанням, сприяють безпеці найбільш вразливих верств населення. Міжнародна організація Фонд Соціальної справедливості створила громадську онлайн-платформу RAZOMua, аби всі небайдужі змогли допомогти українським лікарням у боротьбі з COVID-19. Головна мета проєкту - об'єднати всіх людей, які займаються допомогою, тому команда RAZOMua запрошує долучатися до платформи та координувати зусилля [15]. Таким чином, відбувається сприяння Міністерству охорони здоров'я та Уряду України в реалізації Постанови КМУ № 211 від 11 березня 2020 року та боротьбі із захворюванням.

Фінанси. Одним із найважливіших аспектів взаємодії ІГС та публічної адміністрації є контроль за фінансами. Належний контроль за рухом коштів, податковою і митною політикою є основою для ефективного здійснення бюджетних програм. Наприклад, Рейчел Купер виділяє таку роль IГC, як «Сторож». Завданням IГС стає контроль за діяльністю уряду та притягнення його до відповідальності [16]. У цьому контексті цікавим також є позиція міжнародного фонду «Відродження», який у своїй стратегії на 2019-2022 роки [17] вказує на такий спосіб взаємодії з державою, як сприяння зниженню рівня корупції шляхом забезпечення постійного громадського контролю за дотриманням урядом антикорупційних норм; формування несприйняття корупції в суспільстві; 
стимулювання механізмів підзвітності через зобов'язання України в рамках Ініціативи з прозорості видобувних галузей.

Міжнародна діяльність. ІГС розглядаються як легітимізована сила на світовій арені. Це тому, що багато з них, не маючи на меті національних інтересів, є потенційними захисниками постраждалих груп у всьому світі. Вони вирішують конкретні питання та лобіюють інтереси порядку денного міжнародної спільноти. ІГС підвищують обізнаність щодо важливих тем і включають їх у політичний процес.

Одним із прикладів таких організацій $\epsilon$ «Альянс будівництва миру» - комплексний IГС, який складається із 110 міжнародних організацій, що працюють у 153 країнах світу. Метою його діяльності є вирішення конфліктів, запобігання насильству, сприяння миру. Будується коаліція для формування поля розвитку миру на міжнародній арені, розглядаються питання, занадто комплексні й глобальні для однієї держави чи організації.

Юстиція. Однією з основних сфер діяльності IГC є захист прав і свобод людини. Найчастіше він полягає у представництві інтересів перед суб'єктами публічного адміністрування - правоохоронними органами. Таким чином, ІГС забезпечує інтереси соціально незахищених сфер населення, виконує роль адвоката/представника, який підвищує обізнаність про проблеми, дає право голосу маргінальним колам, виступає за зміни [16].

Amnesty International - міжнародна громадська організація; ІГС. Вона переросла в інтернаціональний рух, що охоплює понад 7 мільйонів людей, які вважають боротьбу за справедливість своєю справою. Основними методами їхньої діяльності є розслідування порушень і зловживань, вимагання від урядів та корпорацій виконання своїх зобов'язань, розвиток правової освіти [19].

При Міністерстві юстиції України щороку формується громадська рада, до складу якої входять представники, висунуті ІГС. Вона виступає консультативно-дорадчим органом, утвореним для участі громадськості в формуванні правової політики. Проаналізувавши Протокол засідання Громадської Ради № 2 від 17 грудня 2019 року, можемо виділити такі напрями її діяльності:

- розгляд проєктів Законів і прийняття рішення про їх підтримку;

- делегування членів Ради для моніторингу і контролю за діяльністю органів Міністерства юстиції України;

- делегування членів Ради для участі в конкурсних комісіях;

- аналіз реалізації постанов, програм, розпоряджень Кабінету Міністрів України та Міністерства юстиції України.

Соціальна сфера. Надзвичайно важливою роллю ІГС в діяльності публічної адміністрації є реа- лізація соціальної політики. В Україні адвокація соціальної сфери ІГС має надзвичайно велике значення, враховуючи постійне недофінансування останньої публічною адміністрацією. До прикладу, статутом Всеукраїнської благодійної організації «Асоціація благодійників України» встановлено такий напрям діяльності, як сприяння підвищенню рівня співпраці між державними органами влади, з одного боку, та громадськості (недержавних неприбуткових організацій, громадян, інших інституцій), з іншого боку, через освітню та організаційну благодійну підтримку подій, які мають важливе значення в сфері благодійності [20].

У цьому напрямі варто звернути увагу на досвід Німеччини, де функціонують суспільно корисні організації, які займаються соціальними проєктами. Соціальні проєкти - головний інструмент їх функціонування та своєрідний стимул подальшого існування. Це означає, що держава не просто фінансує ту чи іншу суспільно корисну організацію, а й виділяє кошти на проєкт, соціальну значимість якого необхідно довести. Таким чином, організації повинні постійно творчо працювати, створювати нові соціальні проєкти. Кожна з них згідно зі своїми завданнями є членом однієї 3 добродійних спілок [21]. Прикладом таких IГC є Максиміліан Кольбе Верк - німецька організація, основною метою якої є взаєморозуміння $\mathrm{i}$ примирення народу Німеччини та жителів країн Східної Свропи - в'язнів концтаборів і жертв репресій періоду Другої світової війни. Вона виділяє матеріальну допомогу, забезпечує лікування, збирає історичні відомості і спогади очевидців [22]. Таким чином, відбувається сприяння діяльності публічної адміністрації в реалізації програм соціального захисту та водночас налагодженні відносин $з$ адміністраціями інших країн.

Екологія. Надзвичайно велика кількість ІГС спрямована на лобіювання екологічних питань, у тому числі шляхом взаємодії з публічними адміністраціями. Так, Громадянська рада корінних народів Гондурасу провадить кампанії з питань лісозаготівлі та будівництва гребель, що будуть впливати на життя корінних народів. "Village Water Zambia» - громадська організація, яка забезпечує постачання води і наведення порядку в сільській місцевості [16]. Із боку таких IГC часто наявна протидія публічній адміністрації в реалізації останньою програм, які можуть шкодити екології. Таким чином, вони фактично набувають статусу узаконеного опонента публічної адміністрації. Однією з найвідоміших організацій у цій cфpepi $€$ «Greenpeace».

Законом України «Про регулювання містобудівної діяльності» встановлено та відповідно до постанови Кабінету Міністрів України «Про Порядок проведення громадських слухань щодо врахування громадських інтересів під час розробки 
містобудівної документації на місцевому рівні» урегульовано порядок розгляду проєктів містобудівної документації на місцевому рівні: генеральних планів населених пунктів, планів зонування територій, детальних планів територій спільно із громадськістю - однією чи більше фізичною або юридичною особою, їх об'єднанням, організаціями або групами. Таким чином, громадяни мають можливість представляти свої інтереси, брати участь в обговоренні впливу будівництва на екологію, висловлювати пропозиції і зауваження, які повинні враховуватися публічною адміністрацією.

Освіта. Для багатьох ІГС освітня діяльність не є основною. Поширення знань стає похідним результатом розв' язання основних завдань-охорониправ, захисту екології і т. д. Таким чином, ІГС допомагають публічній адміністрації в реалізації освітньої політики, адвокують підвищення рівня грамотності населення, проводять контроль за здійсненням освітнього процесу та моніторингу його якості.

Однією зі сфер діяльності ІГС у цьому напрямі $€$ проведення неформальної освіти. Неформальна освіта - систематична освітня діяльність організацій, спрямована на подачу адаптованого під потреби учнів навчального матеріалу, не обтяженого формальностями шкільної програми. Однією з організацій, яка займається її просуванням, $€$ громадська організація «Центр неформальної освіти», що активно сприяє розвитку та популяризації неформальної освіти, а також просуває міжнародні діалоги серед молоді, популяризує волонтерство як форму активного громадянства.

На основі аналізу наведених вище відомостей ми отримали розуміння того, як і в яких сферах відбувається взаємодія ІГС та публічної адміністрації. Шляхом застосування індуктивного методу ми виділили такі ролі ІГС в діяльності публічної адміністрації:

- аудитор (контролер) діяльності публічної адміністрації;

- адвокат/представник суспільства у відносинах із публічною адміністрацією;

- аналітик діяльності публічної адміністрації;

- легальний опонент публічній адміністрації;

- суб’єкт міжнародних відносин - міжнародний медіатор;

- суб'єкт впливу на формування політики публічної адміністрації.

Інститути громадянського суспільства і публічна адміністрація: на шляху до правової держави. Реалізуючи кожну зі сфер, ІГС та публічна адміністрація прямують до спільної мети - побудови правової держави. Формування правової держави, зазвичай, є законодавчо декларованим завданням публічної адміністрації. Водночас найважливішою передумовою правової держави є формування громадянського суспільства, в якому б реально та ефективно забезпечувався вільний і всебічний розвиток кожної особистості, функціонування демократичних громадянських інститутів, що сприяють свободі слова та інформації, гарантують силою громадської думки і суспільною мораллю вільні вибори, існування легальної опозиції та багатопартійність, унеможливлюють узурпацію влади [23, с. 236]. Головне для держави - здатність встановлювати норми для плюралізму державних і приватних суб'єктів. Тобто потрібна така організація державної влади, яка більшою мірою гарантуватиме соціальні права і меншою - займатиметься регулюванням. Ось чому метою правової держави є не стільки підтримка плюралістичної структури громадянського суспільства, скільки саме їі створення [18, с. 135]. Із цього випливає, що публічна адміністрація, реалізуючи державну політику, повинна сприяти формуванню ІГС. ІГС, у свою чергу, розуміючи, що основа держави, їі першоджерело - це громадяни, повинні активно допомагати публічній адміністрації у виконанні iї завдань. Самостійна, легалізована, ініціативна i активна діяльність ІГС у взаємодії з публічною адміністрацією є основою формування правопорядку, забезпечення реалізації прав і свобод та дотримання верховенства права - основоположних чинників творення правової держави.

Висновки. Отже, варто зазначити, що громадянське суспільство є важливою частиною демократичного процесу. Саме під час взаємодії ІГС та публічної адміністрації відбувається реалізація основних засад демократизму шляхом вільної, активної участі громадян у реалізації державної політики. У більшості країн через різні інструменти громадяни можуть висловлювати свої погляди, відстоювати та забезпечувати власні інтереси, впливати наполітичний порядок денний у державі.

Дослідивши основні сфери, в яких здійснюється взаємодія ІГС та публічної адміністрації, ми визначили способи їх взаємодії та загальну роль ІГС у них. Так, зокрема, IГС можуть просувати неформальну освіту, забезпечувати дискусійні майданчики, розгортати дебати щодо важливих соціальних питань, працювати для вирішення конфліктів i подолання їх наслідків, допомагати державі в розв'язанні питань охорони здоров'я, здійснювати належний контроль за рухом коштів, податковою і митною політикою, лобіювати інтереси порядку денного міжнародної спільноти, займатись адвокацією, захищати соціально незахищені верстви населення, порушувати проблемні питання екології, сприяти прозорості й підзвітності СПА тощо. Більшість країн на нормативному рівні забезпечують участь IГС у ПА, створюються органи з координації їх взаємодії та площадки для діалогу.

Нами було розглянуто український та міжнародний досвід участі ІГС у діяльності публічної адміністрації. Кількість міжнародних актів ще раз підтверджують основоположну роль ІГС 
у формуванні правової держави. Щодо міжнародних актів, на які ми звернули увагу при аналізі, тут варто згадати Кодекс Рекомендацій практичної громадянської участі, прийнятий радою Європи у 2009 році, а щодо української нормативної бази - основоположним видалась Національна стратегія сприяння розвитку громадянського суспільства в Україні на 2016-2020 роки, затверджена Указом Президента у 2016 році. Ураховуючи, що Національна стратегія сприяння розвитку інститутам громадянського суспільства в Україні на 2016-2020 роки добігає кінця, пропонується провести комплексний аналіз її виконання і на його основі розпочати розробку нової стратегії.

Нами було досліджено й деякі проблемні аспекти участі громадськості в управлінні державою, адже наразі більшість громадян залишаються політично неактивними, чому сприяє низка факторів, про які було зазначено під час викладу основного матеріалу, а координаційні органи із взаємодії між ІГС та ПА, у свою чергу, є часто неефективними або безініціативними.

Ми вбачаємо такі шляхи вирішення цих ситуацій:

- впровадження програм розвитку відносин інститутів громадянського суспільства та публічної адміністрації;

- введення громадянської освіти;

- забезпечення наявності ефективних судових та позасудових механізмів вирішення спорів;

- забезпечення ефективного механізму звернення громадян;

- наявність досконалої нормативно-правової бази;

- встановлення відповідальності суб’єктів публічної адміністрації за ухилення від надання можливості участі інститутів громадянського суспільства в діяльності, де це передбачено законодавством;

- забезпечення налагодження доступу до інформації про механізми взаємодії інститутів громадянського суспільства з публічною адміністрацією;

- спрощення та забезпечення прозорості механізмів участі населення в діяльності публічної адміністрації, прийнятті рішень, зокрема, через електронну форму участі;

- ведення правильної інформаційної політики;

- підвищення рівня довіри до влади;

- наявність дискусійних платформ для обговорення найважливіших питань.

\section{Jimepamypa}

1. Гегель Г. Философия права. Москва, 1990. С. 228.

2. Московець B.I. Громадськість як інститут громадянського суспільства. Вісник ХНУВС. 2011 № 2(53). C.39.URL:http://www.irbis-nbuv.gov.ua/cgi-bin/irbis nbuv/cgiirbis_64.exe?C21COM=2\&I21DBN=UJRN\&P $\overline{2}$ $1 \mathrm{DBN}=$ UJRN\&IMAGE_FILE DOWNLOAD $=1 \&$ Image file_name=PDF/VKhnuvs_2011_2_7.pdf .
3. Civil Society and Democracy in Global Governance Dr. Jan Aart Scholte Department of Politics and International Studies, University of Warwick CSGR Working Paper No. 65/01. C. 6. URL : https://warwick.ac.uk/fac/ soc/pais/research/researchcentres/csgr/papers/ workingpapers/2001/wp6501.pdf.

4. Про створення єдиної системи залучення, використання та моніторингу міжнародної технічної допомоги: постанова Кабінету Міністрів України № 153 від 15 лютого 2002 p. URL : https://minjust.gov.ua/m/ str_38262.

5. The World Bank - Civil society. URL : https://www.worldbank.org/en/country/japan/brief/ civil-society.

6. Мельник Р.С., Бевзенко В.М. Загальне адміністративне право : навч. посіб. / за заг. ред. Р. Мельника. Київ : Ваіте, 2014. 376 с. С. 42.

7. Кодекс рекомендованої практики громадянської участі в процесі прийняття рішень CONF/PLE(2009) CODE1, прийнятий Конференцією МНУО на засіданні 1 жовтня 2009 p. URL : https://rm.coe.int/16802eedd4.

8. Фундаментальні принципи щодо статусу неурядових організацій в Європі. URL : https://zakon.rada. gov.ua/laws/show/994_209\#Text.

9. Кодекс рекомендованої практики громадянської участі в процесі прийняття рішень CONF/PLE (2009) CODE1, прийнятий Конференцією МНУО на засіданні 1 жовтня 2009 p. URL : https://rm.coe.int/16802eedd4.

10. Національна стратегія сприяння розвитку інститутам громадянського суспільства в Україні на 2016-2020 роки. URL : https://zakon.rada.gov.ua/ laws/show/68/2016\#n20.

11. Кодекс рекомендованої практики громадянської участі в процесі прийняття рішень CONF/PLE(2009) CODE1, прийнятий Конференцією МНУО на засіданні 1 жовтня 2009 p. URL : https://rm.coe.int/16802eedd4.

12. Атаманчук Г.В. Теория государственного управления: курс лекций. 3-е изд., доп. Москва : Омега-Л, 2005.584 c. C. 547.

13. Андріїв М.М. Поняття та структура компетенції органів публічної влади. Теорія та практика державного управління. 2017. № 2(57). С. 1-8. С. 2.

14. Сайт International Committee of the Red Cross (MKЧX). URL : https://www.icrc.org/en/mandate-andmission.

15. Фонд Соціальної справедливості. URL : https://iosj.org.ua/\#rec136216131.

16. What is Civil Society, its role and value in 2018 ? Rachel Cooper University of Birmingham 15 October 2018. URL : https://assets.publishing.service.gov.uk/ media/5c6c2e74e5274a72bc45240e/488_What_is_ Civil Society.pdf.

17. Міжнародний фонд «Відродження»- Стратегія фонду на 2019-2022 роки.

18. Пройсс У . Модели конституционного развития и перемены в Восточной Европе. Полис. 1996. № 4. С. 135.

19. Amnesty International. https://www.amnesty.org.ua/hto-my/.

20. Статут Всеукраїнської благодійної організації "Асоціація благодійників України». URL : https://vboabu.org.ua/img/forall/ststut $\%$ 20asociacia $\%$ 202018.rtf.pdf.

21. Шинелева Л.Т. Общественные неправительственные организации и власть. Москва : Издательско-торговая корпорация «Дашков и Ко», 2002. $220 \mathrm{c.}$

22. Maximilian-Kolbe-Werk.

URL https://www.maximilian-kolbe-werk.de/unsere-arbeit/.

23. Заєць А.П. Правова держава в контексті новітнього українського досвіду. Київ : Парламент. вид-во, 1999. C. 236. 


\section{Анотація}

Чернявська Б. В. Роль інститутів громадянського суспільства в діяльності публічної адміністрації: український та міжнародний аспект. - Стаття.

Автором статті було проведено дослідження ролі інститутів громадянського суспільства в діяльності публічної адміністрації крізь призму українського та міжнародного досвіду. По суті, інститути громадянського суспільства виступають інструментами, необхідними для забезпечення демократії в державі, представляють різні погляди, захищають інтереси громадян, беруть участь у політичних процесах тощо. Відповідно, інститути громадянського суспільства задіяні в різних сфеpax суспільних відносин, таких як: охорона здоров'я, правосуддя, фінанси, освіта, екологія, міжнародні відносини, безпека, соціальна політика тощо.

Автор наводить приклади правового регулювання відносин між інститутами громадянського суспільства та суб'єктами публічного адміністрування, акцентуючи увагу на проблемах таких відносин. Серед основних iз них: відсутність громадянської культури; слабке інформування людей про можливість впливати на державні та політичні процеси; брак довіри; правовий нігілізм; бюрократичні перешкоди. Інститути громадянського суспільства, в тому числі громадські організації, відіграють важливу роль у забезпеченні верховенства права. Цьому сприяють, зокрема, громадський контроль, аудит, правовий захист, аналіз та багато інших методів. Отже, вирішальним завданням публічного адміністрування є сприяння діяльності інститутів громадянського суспільства різними способами.

Автор робить висновок, що найважливішою передумовою верховенства права є формування громадянського суспільства, в якому гарантується вільний та всебічний розвиток кожної людини, функціонування демократичних інститутів, що забезпечують свободу слова та інформації, сила громадської думки і суспільної моралі, вільні вибори, існування легальної опозиціі та багатопартійності. Усе сказане вище робить узурпацію влади неможливою.

Автор пропонує шляхи вирішення проблемних аспектів участі громадськості в публічному адмініструванні, зокрема шляхом вдосконалення нормативно-правової бази, забезпечення ефективного механізму оскарження, забезпечення прозорості механізмів участі громадськості в публічному адмініструванні та їх спрощення, встановлення відповідальності суб'єктів публічного адміністрування за ухилення від сприяння участі інститутів громадянського суспільства в їхній діяльності та процесах прийняття рішень, якщо це передбачено законом тощо.

Ключові слова: громадянське суспільство, інститут громадянського суспільства, громадська організація, публічна адміністрація, верховенство права, правова держава, демократія, громадський контроль.

\section{Summary}

Cherniavska B. $V$. Ukrainian and international aspects of the civil society institutions' role in the activities of public administration. - Article.

The author of the article made an investigation on Ukrainian and international aspects of the civil society institutions' role in the activities of public administration. Essentially, civil society institutions serve as the instruments of civil society required to provide democracy, represent different views, participate in the political process, and others. Accordingly, civil society institutions participate in different fields of public relations, namely: healthcare, justice, finance, education, ecology, international relations, safety, social politics. Public administration is an institute, by which the stated is governed with. In addition, there is a necessity for a dialogue between these institutes. In this vein, the author gives examples of the legal regulation of the relations between civil society institutions and public administration, thus focusing on the problems of such relations. Among the main problems are the lack of civic culture, the fact that people are generally hesitant to the possibility of influencing state and political processes, credibility gap, legal nihilism, bureaucratic obstacles.

Thus, different ways of the stimulation for public administration synergy within the civil society institutions are represented and characterized. Civil society institutions, including public organizations, play an important role in providing the rule of law. This is being done particularly via the public control, audit, legal protection, analysis, and many other methods. Thus, it is the crucial task of the public administration to promote the activities of civil society institutions in various ways.

The author therefore concludes that the most essential prerequisite of the rule of law state is the formation of a civil society in which the free and comprehensive development of each person, the functioning of democratic civil institutions that ensure freedom of speech and information, are guaranteed though the power of public opinion and public morality, free elections, existence of the legal opposition and multi-party system. All the foregoing makes the usurpation of power impossible.

The author offers the ways to solve the problematic aspects of public participation in government, especially by improving the regulatory framework, providing an effective mechanism for citizens to appeal, simplifying and ensuring transparency of mechanisms for public participation in public administration, establishing the responsibility of public administration entities for avoiding participation of civil society institutions in activities where it is provided by law, etc.

Key words: civil society, civil society institution, NGO, civil society organization, public administration, rule of law, constitutional state, democracy, public (social) control. 